UDC 332.87

\title{
PUBLIC UTILITY AREA: \\ SUBSTANTIATION OF THE NEED FOR THE COMPREHENSIVE UPGRADING AND ENHANCEMENT OF THE ENERGY EFFICIENCY
}

Larin Sergey Nikolaevich leading researcher, $\mathrm{PhD}$ in technical sciences Central Economic \& Mathematic Institute of RAS, Moscow

\begin{abstract}
The article presents a brief analysis of the current state of the housing and public utility sector in Russia. According to its results, it is concluded that the sphere of housing and public utility, on the one hand, requires immediate comprehensive modernization of the municipal infrastructure, and on the other, has every reason to become a breakthrough direction for the sustainable development of the domestic economy. The main element of the management of the housing and public utility sector is the housing fund, as well as the institutional agents that operate it. It is established that the housing stock and the functioning municipal infrastructure have significant physical and moral wear and tear. Its presence negatively affects the quality of housing and public utility provided to the population. A number of the most promising areas for the comprehensive modernization of the municipal infrastructure of the housing and public utility sector have been identified on the basis of the introduction of new economic mechanisms that ensure the improvement of the quality of housing and public utility.
\end{abstract}

Key words: public utility area, public infrastructure, comprehensive modernization, public utility services, quality.

\section{СФЕРА ЖИЛИЩНО-КОММУНАЛЬНОГО ХОЗЯЙСТВА: ОБОСНОВАНИЕ НЕОБХОДИМОСТИ КОМПЛЕКСНОЙ МОДЕРНИЗАЦИИ И ПОВЫШЕНИЯ ЭНЕРГОЭФФЕКТИВНОСТИ}

\author{
Ларин Сергей Николаевич \\ ведущий научный сотрудник, кандидат технических наук \\ Центральный экономико-математический институт РАН, Москва
}


Аннотация: В статье представлен краткий анализ современного состояния сферы жилищно-коммунального хозяйства России. По его результатам сделан вывод о том, что сфера жилищно-коммунального хозяйства, с одной стороны, требует незамедлительного проведения комплексной модернизации коммунальной инфраструктуры, а с другой, имеет все основания для того, чтобы стать прорывным направлением устойчивого развития отечественной экономики. Основным элементом управления сферой жилищно-коммунального хозяйства определен жилищный фонд, а также институциональные агенты, осуществляющие его эксплуатацию. Установлено, что жилищный фонд и функционирующая коммунальная инфраструктура имеют значительный физический и моральный износ. Его наличие негативно сказывается на качестве предоставляемых населению жилищно-коммунальных услуг. Определен ряд наиболее перспективных направлений для проведения комплексной модернизации коммунальной инфраструктуры сферы жилищнокоммунального хозяйства на основе внедрения новых экономических механизмов, обеспечивающих повышение качества жилищнокоммунальных услуг.

Ключевые слова: сфера жилищно-коммунального хозяйства, коммунальная инфраструктура, комплексная модернизация, жилищнокоммунальные услуги, качество.

\section{Introduction}

The sphere of housing and public utility is designed to meet the needs of the country's population in high-quality housing and provide the necessary conditions for its normal life. It supports the functioning of the social and industrial infrastructure of municipalities in all regions of Russia. Many researchers note the high social significance of the housing and public utility sector in terms of providing the population of the whole country with highquality housing conditions $[1,2]$. At the same time, this sphere has a significant economic potential, which is directly related to the formation of consumer demand for the works and services of institutional agents operating in it and the availability of wide opportunities for attracting private business. However, the real significance of the housing and public utility sector is determined by a wider range of issues, which, in addition to socio-economic, can reasonably include demographic, technical, environmental, regulatory, political, innovative 
and a number of other aspects in their very different interrelationships with the sustainable development of regions and territorial entities of our country.

Today, the housing and public utility sector provides the population of all regions of Russia with a diversified complex of housing and public utility services (HPUS) that create conditions for their life and form the level of comfort of their living. It ensures that the engineering and technical condition of the housing stock meets the requirements of modern standards, its quality and reliability. In addition, the housing and utilities sector not only reproduces a range of services that contribute to improving the quality of living of the population, but also has a significant impact on the growth of the socio-economic potential of all regions of Russia, their investment attractiveness, creates favorable conditions for the introduction of innovations and the development of private business. That is why the housing and public utility sector needs a comprehensive modernization, the main goal of which should be to bring the quality of the housing and public utility complex provided to the population to the level of international standards while simultaneously expanding their range.

\section{Research purpose}

The purpose of this article is to substantiate the need for a comprehensive modernization of the housing and public utility sector while simultaneously improving the quality and expanding the range of housing and public utility services provided to the population.

\section{Material and methods}

In modern conditions, the housing and utilities sector should be considered as one of the priority socio-economic sectors of the Russian economy. In support of this, the following statistics can be cited.

The housing and utilities sector is one of the largest sectors of the country's economy. According to data for $2019,91,8 \%$ of the total volume of the housing stock in the amount of 3,85 billion square meters of the total area of housing is privately owned. The annual turnover of the housing and public utility sector amounted to more than 5,4 trillion rubles (4,9\% of GDP), of which state and municipal financing of housing and communal services was $13,9 \%$, the population paid about $86 \%$ of the cost of housing and communal services. 118,8 thousand organizations work in the housing and public utility sector and about 3 million people are employed, or more than $4 \%$ of the total number of people employed in the economy [3, 4]. 
The state, reforming the housing and public utility sector, as part of the implementation of the Strategy for the Development of Housing and Public Utility of the Russian Federation for the period up to 2020 [5] and the implementation of a Comprehensive program for the reform and modernization of housing and public utility for the period 2010-2020 [6] provided:

- change in the ownership structure and transfer to private ownership of housing stock enterprises - by $91.8 \%$;

- implementation of the constitutional rights of citizens in the conditions of the beginning of the transfer of housing construction and housing and public utility to self-sufficiency, self-financing, self-government and partially selfregulation;

- financing at the expense of budget funds for the commissioning of: objects of the communal structure of the social sphere - kindergartens, schools, other educational institutions, hospitals, polyclinics, cultural and sports facilities, objects of the public structure of the road infrastructure;

- full or partial payment for the construction or purchase of housing for citizens at the expense of:

- subsidizing interest rates on mortgages, including mortgages in rural areas (with banks monitoring the solvency of the population);

- provision of targeted subsidies for the construction or purchase of housing, including in the form of state housing certificates;

- using the funds of the "maternity capital";

- payment for certain categories of citizens of a part of housing and public utility in the form of targeted subsidies, benefits and other social support in the manner and on the terms established by regulatory legal acts of the Russian Federation, subjects of the Federation and local self-government bodies;

- financing of state and municipal programs for the resettlement of emergency housing, its demolition and disposal;

- allocation of land plots for free or sale at affordable prices: waiting lists for improving housing conditions, large families and other categories of families for individual housing construction, construction of houses of housing cooperatives or housing and construction cooperatives, as well as under the program "Far Eastern hectare".

Financing by the population of the purchase of built housing, as well as housing and public utility, brings to the country's economy annually from 8.5 to 9.0 trillion rubles [3]. 
Housing construction and the functioning of the housing and public utility sector have become the "locomotive" of the country's economic development, attracting additional funds from the population and providing a high multiplier effect due to:

- development of the land market for housing construction and the network of intra-village roads;

- manufacturing of the public equipment, including autonomous systems;

- growth in the production of building materials, products and structures, sales of furniture, household appliances, textiles, household utensils, etc.

However, negative macroeconomic trends, a reduction in real disposable incomes of the population, the high cost of bank loans for housing construction with the introduction of the escrow account system, have created a problem of rising housing costs in apartment buildings and slowing down the demand for such housing. The increase in the volume of housing commissioning provided for by the national project "Housing and the Urban Environment", with the development of individual housing construction with associated infrastructure facilities, requires a significant increase in the area of territories prepared in urban planning for development. The number of families registered for improving housing conditions is 2,36 million, and 99 thousand or $4 \%$ of the needy families who received housing for the year, that is, it will take about 20 years to fulfill the state's obligations to provide housing for all those in need [7].

The housing and public utility sector is in a different condition across the subjects of the Russian Federation and municipalities. It is characterized by: monopolism of resource-supplying organizations of housing and public utility; the complexity of transferring this sphere to self-sufficiency, self-financing and selfgovernment; underdevelopment of institutions of housing and public utility customers in the form of responsible homeowners and homeowners associations in the MDC; inefficiency of management companies. Financial restrictions on the development of the housing and public utility, associated with the poverty of certain groups of the population to pay for housing and public utility, while maintaining cross-subsidization of the population by enterprises, lead to an increase in debt for housing and public utility (more than 1,3 trillion. rubles as of 01.01.2019). The unprofitability for 10 years of the majority of housing and public utility enterprises, and therefore, to a decrease in the effectiveness of the development of mechanisms for attracting extra-budgetary investments for the modernization of the system and housing and public utility. 
The main problems of the housing and utilities sector are the incompleteness and braking of reforms to eliminate administrative barriers in the systems of contract bidding, personnel training, pricing, technical regulation, and the development of civil society [7]. At the same time, the experience of 2020 showed the stability of the housing and communal services sector to adverse conditions, including those related to overcoming the impact of the coronavirus pandemic on the country's economy. In the housing and utilities sector as a whole, it was possible to maintain the volume of work performed. Thanks to the investments of the population, the total volume of housing commissioning has also been preserved, and the commissioning of individual housing construction houses has been increased.

\section{Results and discussion}

The specifics of the production and economic activities of housing and public utility enterprises as institutional agents are diverse and have their own characteristics. We will indicate only three fundamental signs concerning the organizational, sectoral and institutional structure of enterprises in this sphere, on the basis of which it is possible to get the most complete idea of the features of their functioning.

The organizational specificity of the housing and public utility sector is that it includes housing and public enterprises [8]. At the same time, the production and economic activities of housing enterprises are aimed at forming the human habitat, providing it with the benefits of a civilized life. It is related to the existing housing stock, its maintenance and operation, as well as to improving the efficiency of its management. The production and economic activity of municipal enterprises has a direct impact on the household and sanitary and hygienic conditions of the population. It is connected with the production and supply of various types of housing and public utility to specific consumers.

The industry specifics of the housing and public utility sector allow us to consider it, on the one hand, as a complex, but unified multi-industry complex, which appears in this sense in many forms of statistical reporting at the macroeconomic level. On the other hand, the production structure of the housing and public utility sector includes about 30 types of production and economic activities within the framework of independent industries, such as:

- heat power industry - in the part of heat, electric power and consumer gas supply;

- water supply - in the part of potable water supply;

- sewer system - in the part of removal of sewage; 
- amenities - in the part of solid waste withdrawal and urban garden;

- construction - in the part of reproduction and capital repair of the housing fund;

- lifting mechanisms - in the part of mounting and operation of cargo \& passenger elevators in block of flats;

- statistic reporting - in the part of inventory of main funds;

- scientific research - in the part of performance of project, technologic works, research and development $(\mathrm{R} \& \mathrm{D})$;

- education - in the part of training and retraining of the personnel, as well as some others [8].

In the process of production and economic activity of economic entities in the housing and public utility sector, specific industry features of each of them are manifested, which are associated with the volume and functional state of fixed assets, the directions of their activities, the investment attractiveness of a particular industry, as well as the peculiarities of its development in relation to a specific region of the country. The totality of these features is manifested in the different directions of production and economic activities of economic entities in the housing and public utility sector and their interest in its financial results.

From the standpoint of institutional theory, every economic entity has every reason to be considered an institutional agent interested in improving its financial stability and making a profit $[9,10]$. However, its interests often contradict or even conflict with the interests of institutional agents of other industries in the process of their interactions aimed at the production of housing and public service and their provision to potential consumers. Today, in the housing and utilities sector of each region, there are many institutional agents representing both their own interests and the interests of various industries. Among them are the following:

- institutional agents in person of municipal customer services, represented by housing committees and departments;

- direct consumers of housing and public utility, which include homeowners (individuals and legal entities) acting both independently and through homeowners associations (HOAs) or management companies (MC) [8].

Between these two varieties, in the chain of production and provision of various types of housing and public utility services, various sets of institutional agents of different forms of ownership, engaged in the supply and supply of resources, financial and legal services, as well as the provision of other specialized services, carry out their intermediary activities. 
Taking into account these specific features, the housing and public utility sector appears as a complex socio-economic system, which is a specific object of management both at the state and at the regional level. Its socio-economic development is determined not only by the laws of the economy, but also by the dynamics of changes in the demographic situation, the presence of effective demand of the population and a number of other similar factors, the importance and significance of which vary significantly in different regions of Russia.

In the conditions of a constant shortage of free financial resources, the state has actually shifted responsibility for the development of the industry to its institutional agents, while not giving up its leading role in its reform and further development. As a result, the housing and utilities sector today should be considered as a complex dynamic system in which many institutional agents function simultaneously. However, the regulatory and legal relations between them continue to be regulated not by contractual terms, but by by-laws of federal, regional and municipal authorities. If we add here the fact that each institutional agent pursues its own goals and interests in the implementation of entrepreneurial activity, it becomes clear how much diversity is characterized by a complex of interactions between them in relation to different regions of our country.

Despite the efforts made recently at all levels of government, as well as due to the above circumstances, the housing and utilities sector today remains one of the most problematic and least denationalized sectors of the Russian economy [11, 12]. The introduction of market mechanisms in it faces great difficulties, and the results obtained in the course of their work do not provide normal conditions for the effective functioning of most of its institutional agents.

The combination of factors for the effective modernization of the municipal infrastructure of the housing and public utility sector is complex and diverse. First of all, it should highlight the measures aimed at improving the quality of housing and public utility and the rational use of energy resources as the most consumed and expensive in the housing and public utility sector.

The share of energy consumption in the housing and public utility sector in Russia as a whole is more than $30 \%$ of the total power consumption. At the same time, the housing and utilities sector also has the most significant energy saving potential of all industries. Thus, reducing the consumption of thermal energy for the operation of heating and hot water supply systems of the MDC can provide about $60-65 \%$ of the potential energy savings in this area [3, 4]. 
Let's briefly focus on the most significant of them and those that at the moment immediately require implementation.

The primary one is to reduce the significant wear of heat supply networks, as well as the replacement of short-lived insulating materials that have insufficient heat conservation indicators. Currently, these materials are being replaced by better thermal insulation of heat supply networks made of rigid polyurethane foam. The estimated life of its operation is up to 40 years, but at the moment there is not enough capacity in Russia for its production in quantities that allow for the modernization of worn-out heat supply networks in a short time.

An effective measure to save energy resources should be the transition from district heating systems of the MDC to individual heat supply systems, as well as the mandatory equipping of heat supply systems in apartments with electronic heat distribution meters and heat regulators for heating radiators [13]. However, for its implementation, it will be necessary to ensure the production of a sufficient number of heat distribution meters and temperature controllers, which is a rather difficult problem for the Russian industry.

Optimization of the management of existing district heating systems will be less costly compared to the previous event. Its implementation will allow us to quickly implement comprehensive energy saving solutions, thereby ensuring a significant economic effect.

The level of thermal protection of most of the MDC today is several times lower than the established standards. As the main measure aimed at bringing this indicator in line with regulatory values, standard complex reconstruction projects were developed, providing for the replacement of all communications, the installation of energy-efficient double-glazed windows, thermal insulation of external walls with expanded polystyrene or mineral wool insulation, as well as a number of other measures aimed at reducing heat loss. Practice shows that during the subsequent operation of the reconstructed MDC, the volume of thermal energy used for heating was reduced by more than two times [14].

An effective measure for the comprehensive modernization of the housing and public utility infrastructure should be the use of active supply and exhaust ventilation systems with the installation of heat recovery devices [13]. The principle of their operation allows you to significantly reduce the energy consumption for heating the MDC by using the heat removed from the residential building through the exhaust ventilation channels of the already spent air, for partial heating of the air re-entering the system from the environment. 
The list of energy saving measures can be continued, but the ones listed above are quite enough to confirm the presence of a significant potential for energy saving and saving other resources in the housing and utilities sector. With the competent development and practical implementation of the energy saving policy as part of the comprehensive modernization of the housing and public utility infrastructure, it is possible not only to increase various characteristics of the quality and comfort of housing, but also to significantly reduce the costs of maintaining the MDC and paying for housing and public utility due to all-round resource savings.

Among other areas of comprehensive modernization of the municipal infrastructure of the housing and public utility sector, attention should be paid to ensuring the interaction of institutional agents in this sphere on the basis of the introduction of new economic mechanisms that contribute to improving the quality of housing and public utility. These include solving a number of problems of interaction of institutional agents of the housing and public utility sector in conditions of probabilistic uncertainty, namely: evaluating the effectiveness and risks, formalizing the interaction of institutional agents using probabilistic modeling tools, making decisions in conditions of the need to take into account the influence of many criteria, as well as formal and informal factors of different orientation.

\section{Opinions}

The effective functioning of the housing and public utility sector in Russia in modern conditions is impossible without an accelerated modernization of its public infrastructure and improving the quality of housing and public utility provided. The implementation of these transformations in this area should be based on the maximum consideration of the economic, financial and other interests of its institutional agents as producers of housing and public utility services, as well as homeowners as their direct consumers. For this purpose, an analysis of the current state of the housing and public utility sector was carried out, and a number of promising directions for the modernization of its communal infrastructure and improving the quality of energy saving services provided by housing and communal services and ensuring effective interaction of institutional agents in this sphere were identified.

\section{Bibliography}

1. Kirillova A.N. Strategic Potential and Key Factors of the Development of Housing and Public Utility Sector // Real Estate: Economics, Management. - 2018. №3. P. 12-16. 
2. Public Utility Sector and Life Quality in the XXI Century: Economic Models, New Technologies and Management Practice: Monograph / Y.P. Silin, G.V. Astratova etc.; ed. by Y.P. Silin, G.V. Astratova. - Moscow, Ekaterinburg: Naukovedenie Publishing Center, 2017. - 600 p.

3. Data from the official site of the Federal State Statistics Service [Electronic resource]. URL - http://www.gks.ru/ (date of address 20. 07.2021).

4. Housing Sector in Russia. 2019: Statistical Book / Rosstat, 2019. - 78 p.

5. Development Strategy of Housing and Public Utility Sector of the Russian Federation for the period till 2020. Approved on 26.01.2016 by the decree of the Government of the Russian Federation № 80-p.

6. Comprehensive Program for the Reformation and Modernization of the Public Utility for the Period of 2010-2020. Approved on 02.02.2010 by the decree of the Government of the Russian Federation № 102-p.

7. Strategy of the Development of the Construction Area and of the Public Utility Sector of the Russian Federation till 2035. Project.

8. Larin S.N. Analysis of Modern Transformations in the Sphere of the Public Utility Sector // Successes of Modern Science and Education, 2017. Vol. 5. №4. P. 32-37.

9. Kleiner G.B. Institutional Dynamics of the National Economics: General Actor's Role // Materials of the V International Scientific Conference «Institutional Economics: Development, Teaching, Applications». Ed.by G.B. Kleiner. - M.: GUU Publishing House, 2017. P. 9-11.

10. Lvov D.S. Introduction to Institutional Economics. - M.: Economics, 2019. $-987 \mathrm{p}$.

11. Slanchenko L.I., Valkovich O.N. Problems of the Enhancing of Activities of the Housing and Public Utility Complex // Stable Development Economics, 2017. №1(29). P. 246-250.

12. Sokolova S.A., Borisova K.V., Problems of the Public Utility Sector // Fundamental Reseacrh, 2016. №11.4. P. 870-872.

13. Energy Saving Technologies of MDC: From State to a Separate Apartment [Electronic resource]. URL - https://www.gkh.ru/article/102272energosberegayushchie-tehnologii-mkd (date of address 20.07.2021).

14. Malmygina K.Y. Possibilities for the Increase of the Energy Efficiency of a Block of Flats // Young Scientist. 2018. № 44 (230). P. 80-83 [Electronic resource]. URL - https://moluch.ru/archive/230/53540/ (date of address: 20.07.2021). 